\title{
Production and Optimization of Lipase Enzyme from Mesophiles and Thermophiles
}

\author{
Jaiswal $\mathbf{A}^{1}$, Preet $\mathbf{M}^{2}$ and Tripti $\mathbf{B}^{3^{*}}$
}

Codon Biotech Pvt. Ltd., India

\begin{abstract}
Lipases are enzymes which catalyze the hydrolysis of triacylglycerol to free fatty acids and glycerol. In the present study bacterial cultures were isolated from industrial and oil spilled areas and was screened for Lipase production and activity. Seven bacterial strains were found to have lipolytic ability. These bacterial strains were grown in production media and the lipase enzyme produced was estimated. After optimization of factors like $\mathrm{pH}$, temperature, carbon source, nitrogen and incubation time etc. a maximum lipase enzyme activity of $8 \mathrm{U}$ was obtained in the mesophilic bacteria: $P$. mirabilis when sunflower oil was used as a substrate, $\mathrm{pH}$ was 6 and temperature was $37^{\circ} \mathrm{C}$. B. coagulans, another mesophile produced $7.5 \mathrm{U}$ of lipase enzyme. Thermophiles: $P$. stutzeri, G. stearothermophilus and $B$. sporothermodurans which were isolated, screened for lipase activity and characterized, showed highest lipase activity of $7 \mathrm{U}$ at $50^{\circ} \mathrm{C}$.
\end{abstract}

Keywords: Lipase; Lipase activity; Mesophiles; Thermophiles; Optimization

\section{Introduction}

Lipases (triacylglycerol lipases EC 3.1.1.3) are enzymes that catalyze the degradation of fats and oils and convert them into fatty acids and glycerol $[1,2]$. Triacylglycerols are the main substrates for lipases. Lipases are produced by substrates such as natural oils, synthetic triglycerides and esters of fatty acids. Bacterial lipases are used extensively in food and dairy industry for the hydrolysis of milk fat, cheese ripening, flavour enhancement and lipolysis of butter fat and cream [3]. Lipases are used in detergent industry as additives in washing powder, in textile industry to increase the absorbency of the fabrics also for synthesis of biodegradable polymers and for different trans esterification reactions [4-7].

Lipase enzyme has also found use as a catalyst for production of different products used in cosmetic industry in pulp and paper industry in synthesis of biodiesel degreasing of leather and also in pharmaceutical industry [8-11]. Bacterial lipases are glycoproteins, but some extracellular bacterial lipases are lipoproteins. Most of the bacterial lipases reported so far are constitutive and are non-specific in their substrate specificity and a few bacterial lipases are thermostable [12]. Among bacteria, Achromobacter sp., Alcaligenes sp., Arthrobacter sp., Pseudomonas sp., Staphylococcus, Serratia sp. and Chromobacterium spp. have been exploited for the production of lipases [13].

In the present study seven lipase producing bacterial cultures were isolated from oil spilled soil and were further used for lipase production. Generally, high productivity of lipase has been achieved by culture medium optimization. Different oil sources, nitrogen sources and physicochemical factors such as $\mathrm{pH}$, temperature and incubation time were studied to check their influence on microbial lipase production. These enzymes are generally produced in presence of oil source with respected to conditions like temperature, $\mathrm{pH}$ and incubation times [14].

\section{Material and Methods}

\section{Collection of soil sample}

The collection of the soil samples was done from industrial and oil spilled industrial areas of Noida. The soil samples were collected in sterile plastic bags and sealed. All samples were labeled with a permanent maker.

\section{Isolation of lipase producing bacterial cultures}

The serial dilution of sample soil was done in 5 test tubes and plated on oil containing mineral media and incubated at $37^{\circ} \mathrm{C}$ for $24 \mathrm{~h}$. After incubation the bacterial colonies were characterized by gram staining and maintained on the nutrient agar slant.

\section{Screening of strains for extracellular lipase}

Qualitative analysis of lipase producing micro-organism was carried out by single line streaking of pure culture inoculates obtained through zigzag streaking on mineral lipid emulsion agar media and egg yolk agar media. The plates were incubated at $37^{\circ} \mathrm{C}$ for $48 \mathrm{~h}$. Lipolytic activity and lipase production was indicated by the formation of zone around the bacterial colonies on mineral lipid emulsion and egg yolk agar plate.

\section{Characterization of lipase producing bacterial cultures}

The characterization of bacterial culture was done by biochemical tests. Biochemical test were used for the identification of isolates bacteria culture for lipase enzyme production. Different Biochemical tests were performed to prove the identity of isolated bacterial culture. Urease, carbohydrate, nitrate, SIM medium, IMVIC test, starch, casein hydrolysis test, catalase test, Acetate, high concentration of $\mathrm{NaCl}$ test, etc., were used for identification. The bacteria strains were further identified using $16 \mathrm{~S}$ rRNA gene sequence analysis and BLAST comparison online. The isolated bacteria cultures were inoculated in mineral lipid emulsion broth media. The OD of lipase was taken at $600 \mathrm{~nm}$ for 4 days.

Thermophilic characterization: Thermophilic characterizations were analyzed by were culturing the isolated organisms at high temperature $\left(50^{\circ} \mathrm{C}\right)$ and the thermophilic property of these isolated strains was established.

${ }^{*}$ Corresponding author: Tripti B, Codon Biotech Pvt. Ltd., India, Tel: 01204311464 E-mail: tripti.codonbt@gmail.com

Received November 30, 2016; Accepted June 06, 2017; Published June 13, 2017

Citation: Jaiswal A, Preet M, Tripti B (2017) Production and Optimization of Lipase Enzyme from Mesophiles and Thermophiles. J Microb Biochem Technol 9:126-131. doi: 10.4172/1948-5948.1000355

Copyright: () 2017 Jaiswal A, et al. This is an open-access article distributed under the terms of the Creative Commons Attribution License, which permits unrestricted use, distribution, and reproduction in any medium, provided the original author and source are credited. 


\section{Fermentation (production) media}

Fermentation media containing different oil types as carbon source were used for batch fermentation for producing lipase using the isolated bacterial culture. The medium used contained the following composition; Peptone: $5 \mathrm{~g} / \mathrm{l}, \mathrm{KH}_{2} \mathrm{PO}_{4}: 2.5 \mathrm{~g} / \mathrm{l}$, Glucose: $1 \mathrm{~g} / \mathrm{l}$, Potassium chloride: $0.5 \mathrm{~g} / \mathrm{l}, \mathrm{MgSO}_{4}: 0.5 \mathrm{~g} / \mathrm{l}, \mathrm{CaCl}_{2}: 0.5 \mathrm{~g} / \mathrm{l}$, Oil: $15 \mathrm{ml}$. The media was autoclaved at $121^{\circ} \mathrm{C}$ for $15 \mathrm{~min}$. After autoclaving, the isolated bacterial cultures were inoculated in the fermentation Medias. Shake flask culture was carried out in $250 \mathrm{~mL}$ Erlenmeyer containing the above media. The flasks were inoculated with $10 \%$ seed culture and incubated at $37^{\circ} \mathrm{C}$ and $220 \mathrm{rpm}$ for a period of 4 Days. The time-course growth curve of isolated organisms was plotted to $8 \mathrm{~h}$ after incubation.

Bioreactor culture: Batch fermentation was performed using the above media with different carbon and nitrogen sources. The reactor was inoculated with $10 \%$ seed culture in log phase and fermentation was carried out according to type of medium. The lipase activity was measured at different time after incubation.

\section{Lipase activity}

After $24 \mathrm{~h}$ of inoculation the fermentation broth were taken in falcon tubes. These falcon tubes were centrifuged for 10 minutes at $10000 \mathrm{rpm}$ and the supernatant was then used as the crude enzyme. This crude enzyme was then tested for its enzyme activity by titrating it against $0.05 \mathrm{M} \mathrm{NaOH}$. The amount of $\mathrm{NaOH}$ used the amount of acid present in the solution which was directly proportional to the amount of lipase produced [15]. Acid value was calculated by the formula:

$\mu \mathrm{mol}$ fatty acid $/ \mathrm{ml}(\mathrm{U})=\frac{(\mathrm{ml} \mathrm{NaOH} \text { for sample }-\mathrm{ml} \mathrm{NaOH} \text { for blank }) \times \mathrm{N} \times 1000}{\mathrm{M}}$ Where:

$\mathrm{U}=\mu \mathrm{mol}$ of fatty acid released $/ \mathrm{ml}$

$\mathrm{N}=$ the normality of the $\mathrm{NaOH}$ titrant used (0.05 in this case)

$\mathrm{M}=$ Total volume of reaction mixture used

One lipase unit has been defined as the amount of the enzyme that releases one $\mu \mathrm{mol}$ fatty acid per $\mathrm{ml}$ under standard assay conditions $(\mathrm{U}=\mu \mathrm{mol}$ of fatty acid released $/ \mathrm{ml})[16]$.

\section{Optimization for lipase enzyme production}

To increase the production and the productivity of the lipase enzyme, different physiological parameters were studied like $\mathrm{pH}$ temperature, carbon source, and incubation time, inoculum, etc. The optimization of lipase production was carried on the variation of physical and chemical parameters of fermentation medium.

Effect of temperature: The effect of temperature was mostly used for the selection of optimum temperature for the production of lipase enzyme. The fermentation media were inoculated and then incubated at different temperature such as $25^{\circ} \mathrm{C}, 37^{\circ} \mathrm{C}$ and $50^{\circ} \mathrm{C}$.

Effect of $\mathbf{p H}$ : The fermentation media were prepared having different $\mathrm{pH}$ such as 4, 6 and 8 inoculated by the bacterial cultures. The lipase activity was estimated and the optimum $\mathrm{pH}$ was selected for maximum lipase enzyme production.

Effect of different oils: Different oils were mostly used as carbon sources. Different oils like mustard oil, soyabean oil and sunflower oil were used in fermentation media. The media was incubated at $37^{\circ} \mathrm{C}$ and the lipase activity was estimated.

Effect of incubation: Optimization of incubation period was done by the incubation of fermentation media for different times. The fermentation medias were prepared and inoculated with the isolated bacteria in conical flask. The conical flask was incubated for different time intervals like such as $24,48,72$ and $96 \mathrm{~h}$. The lipase production was determined for all the incubation periods.

Effect of nitrogen sources: The various nitrogen sources including malt extract, peptone, ammonium sulphate, yeast extract, beef extract, meat extract and soyabean extract were supplemented to the production media.

\section{Results}

Isolation of lipolytic bacterial cultures from industrial and oil contaminated soils resulted in characterization and identification of 7 cultures. Seven strains were identified by gram staining and purified by sub culturing on agar plates

\section{Qualitative screening for lipase activity}

Qualitative analysis of lipase producing micro-organism was carried out by single line streaking on mineral lipid emulsion agar media. The lipase utilizing bacteria were grown on lipid emulsion agar plates. The lipase producers formed a clear zone of hydrolysis on these plates. The cultures from each of the slants were first straight line inoculated on the Egg yolk agar plates. Clear zone was produced in all strains. The isolated bacteria cultures were inoculated in mineral lipid emulsion broth media. The OD of lipase was taken at $600 \mathrm{~nm}$ for 4 days. The time-course growth curve of isolated organisms was plotted to $8 \mathrm{~h}$ after incubation (Table 1 and Figure 1).

The isolated bacteria cultures were inoculated in mineral lipid emulsion broth media. The OD of bacterial growth was taken at 600 nm every day as shown in Table 2 and Figure 1. After screening of the bacteria cultures, they identification by biochemical tests and sequence analysis.

Depending upon the biochemical tests, sugar utilization results and sequence analysis of the 16S rRNA gene, identification of the unknown bacterial strains was done on basis of similarity index after comparison

\begin{tabular}{|c|c|c|c|c|c|c|c|}
\hline $\begin{array}{c}\text { Bacterial } \\
\text { cultures }\end{array}$ & Strain 1 & Strain 2 & Strain 3 & Strain 4 & Strain 5 & Strain 6 & Strain 7 \\
\hline $\mathbf{1}^{\text {st }}$ day & 0.18 & 0.52 & 0.52 & 0.43 & 0.37 & 0.41 & 0.53 \\
\hline $\mathbf{2}^{\text {nd }}$ day & 0.61 & 0.77 & 1.02 & 1.04 & 0.71 & 0.82 & 1.02 \\
\hline $\mathbf{3}^{\text {rd }}$ day & 1.14 & 1.42 & 1.67 & 1.81 & 1.21 & 1.58 & 1.67 \\
\hline $\mathbf{4}^{\text {th }}$ day & 1.15 & 2.24 & 1.90 & 2.13 & 2.02 & 2.11 & 2.15 \\
\hline
\end{tabular}

Table 1: OD of growth of bacterial cultures on mineral lipid emulsion broth culture at $600 \mathrm{~nm}$.

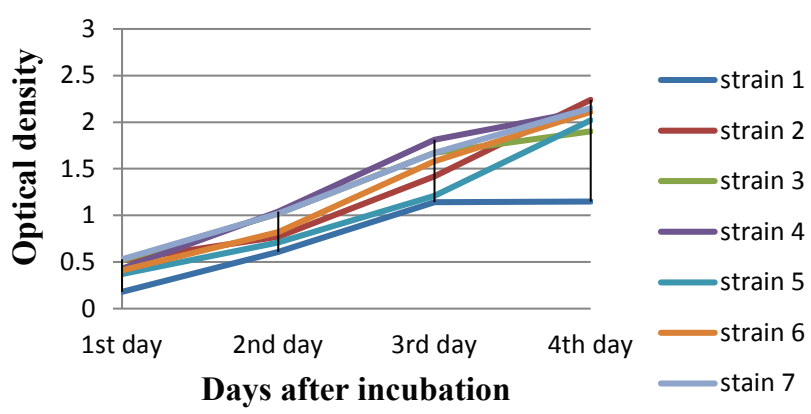

Figure 1: Growth of bacteria culture in mineral lipid emulsion broth media 


\begin{tabular}{|c|c|c|c|c|c|c|c|c|}
\hline S. No. & Type of test & Culture 1 & Culture 2 & Culture 3 & Culture 4 & Culture 5 & Culture 6 & Culture 7 \\
\hline 1. & Lactose & - & - & - & - & + & - & - \\
\hline 2. & Fructose & - & + & + & - & + & & \\
\hline 3. & Glucose & + & - & - & + & + & + & + \\
\hline 4. & Sucrose & - & + & + & - & + & + & + \\
\hline 5. & Maltose & - & + & + & - & + & + & + \\
\hline 6. & Manitol & - & - & - & - & + & - & - \\
\hline 7. & Glycerol & - & + & - & - & - & & \\
\hline 8. & Starch & - & + & - & - & + & & \\
\hline 9. & Sorbitol & - & - & - & - & - & & \\
\hline 10. & Arabinose & - & - & - & - & + & & \\
\hline 11. & Xylose & + & - & - & + & + & - & - \\
\hline 12. & Ribose & - & - & + & - & + & & \\
\hline 13. & Citrate test & + & - & - & + & - & - & - \\
\hline 14. & Acetate test & + & - & - & + & - & & \\
\hline 15. & MR test & - & + & - & - & + & - & - \\
\hline 16. & VP test & - & - & - & - & - & - & + \\
\hline 17. & Indole test & + & - & + & + & - & - & - \\
\hline 18. & $7 \% \mathrm{NaCl}$ test & - & - & - & - & + & + & + \\
\hline 19. & Casein hydrolysis test & - & + & - & - & - & & \\
\hline 20. & Starch hydrolysis test & + & + & + & + & + & & \\
\hline 21. & Nitrate test & + & - & + & - & $+/-$ & - & + \\
\hline 22. & Urease test & + & + & - & + & - & - & - \\
\hline 23. & Acetate test & + & - & - & + & - & & \\
\hline 24. & Sim media test & + & - & + & - & - & & \\
\hline 25. & Catalase test & + & + & + & + & + & + & + \\
\hline 26. & Growth at $45^{\circ} \mathrm{C}$ & + & + & + & - & + & + & + \\
\hline
\end{tabular}

Table 2: Biochemical tests results for all the bacterial isolates.

on BLAST. The results showed that strains 2-5 were mesophilic bacteria but strainS1, S6 and S7 were thermophiles.

\section{S1 - Pseudomonas stutzeri - 93\%}

S2 - Staphylococcus hominis - $96 \%$

S3 - Bacillus coagulans - 95\%

S4 - Proteus mirabilis - 78\%

S5 - Paenibacillus lactis- $87 \%$

S6 - Geobacillus stearothermophilus- 96\%

S7 - Bacillus sporothermodurans- $96 \%$

Fermentation media containing different oils as carbon source were used for batch fermentation for producing lipase using the isolated bacterial cultures. The bacterial strains were inoculated in the production media and amount of lipase enzyme produced was calculated using titration. Variations in $\mathrm{pH}$, temperature, carbon source and incubation time resulted in higher production of lipases.

Different oils were mostly used as substrate for enzyme production for e.g. mustard oil, soyabean oil, and sunflower oil. The enzyme units were calculated and the maximum lipase enzyme activity obtained was $7 \mathrm{U}$ which was produced when sunflower oil was used as a substrate by $P$. mirabilis on $6^{\text {th }}$ day and B. coagulans produced 6.5U. Soyabean oil gave the next highest lipase enzyme activity by $B$. coagulans, $P$. mirabilis and S. hominis. The enzyme activity is shown in Figures 2-4.

The effect of temperature was mostly used for the selection of optimum temperature for the production of lipase enzyme. Different temperature such as $25^{\circ} \mathrm{C}, 37^{\circ} \mathrm{C}$ and $50^{\circ} \mathrm{C}$ were used to check the optimum temperature for the lipase production. The maximum lipase enzyme activity was obtained at $37^{\circ} \mathrm{C}$ and $50^{\circ} \mathrm{C}$ when the mesophiles and thermophiles were considered separately. The Mesophilic cultures of $B$. coagulans, $P$. mirabilis and $S$. hominis- gave highest lipase activity (8.5U-7.5U) at $37^{\circ} \mathrm{C}$ while thermophilic cultures like P. stutzeri, G. stearothermophilus and $B$. sporothermodurans gave maximum lipase activity (6.5U) at $50^{\circ} \mathrm{C}$ as shown in Figure 5. It was surprising to observe that $P$. stutzeri gave similar lipase activity $(6.5 \mathrm{U})$ at both $37^{\circ} \mathrm{C}$ as well as $50^{\circ} \mathrm{C}$.

The effect of $\mathrm{pH}$ on lipase activity was observed for the selection of optimum $\mathrm{pH}$ of fermentation medium for the production of lipase enzyme. The fermentation media having different $\mathrm{pH}$ such as 4,6 and 8 were used. The maximum lipase enzyme activity was produced at $\mathrm{pH} 6$. The maximum lipase enzyme activity obtained was $8.5 \mathrm{U}$ on $4^{\text {th }}$ day at $\mathrm{pH}$ 6 media by $P$. mirabilis as shown in Figure 6. B. coagulans also produced $7.5 \mathrm{U}$ of lipase enzyme on the $6^{\text {th }}$ day at $\mathrm{pH} 6$. Thus, the optimum $\mathrm{pH}$ for maximum lipase enzyme activity is $\mathrm{pH}$ 6. G. stearothermophilus and $B$. sporothermodurans produced less enzyme activity as the reaction was carried out at $37^{\circ} \mathrm{C}$.

The nitrogen sources were used for lipase production in this study. Among the different nitrogen sources tested, soyabean extract was found to be the best among all the nitrogen sources. The production of lipase activity was $8 \mathrm{U}$ as shown in Figure 7; whereas in other nitrogen sources the lipase production was in the range of 2-7U.

\section{Discussion}

The present study deals with isolation of new and novel bacterial cultures which have higher production levels for lipases. After screening of soil microbes, 7 strains were identified by gram staining and purified by sub culturing on agar plates $\&$ slants. 


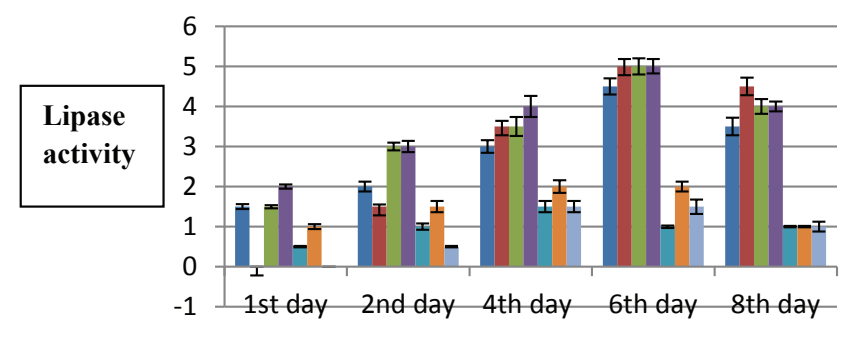

Day after incubation

\author{
P.stutzeri \\ - S.hominis \\ B.coagulans \\ - P.mirabilis \\ P.lactis \\ G.stearothermophilus \\ B.sporothermo
}

Figure 2: Lipase production with mustard oil as substrate.

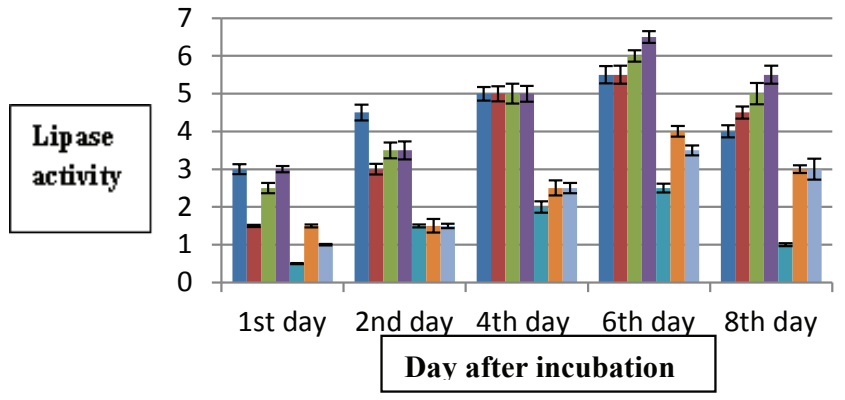

$\square$ P.stutzeri
$\square$ S.hominis
B.coagulans
P.mirabilis
P.lactis
G.stearothermophilus
B.sporothermo

Figure 3: Lipase production with soyabean oil as substrate.

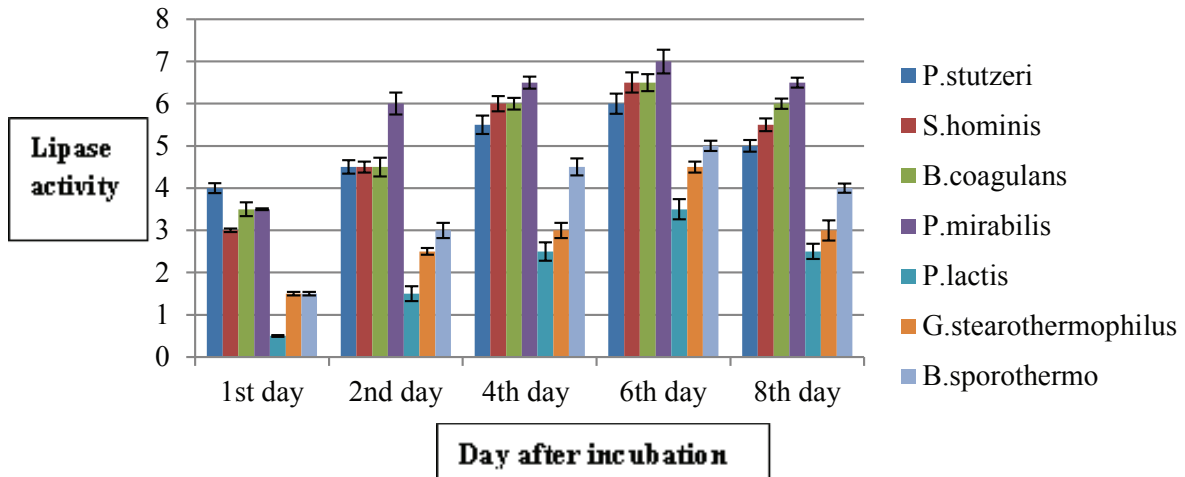

Figure 4: Lipase production with sunflower oil as substrate.

Different Biochemical tests were performed to identify the isolated bacterial cultures. Depending upon the biochemical tests, sugar utilization results and sequence analysis of the 16S rRNA gene. The results showed that: (1) P. stutzeri (93\%), (2) S. hominis (96\%), (3) B. coagulans (95\%), (4) P. mirabilis (78\%), (5) P. lactis (97\%), (6) G. stearothermophilus (96\%) and (7) B. sporothermodurans (96\%).

P. stutzeri and B. coagulans have been shown to produce Lipase in other studies also. But in the present study the lipase enzyme activity obtained is very high as compared to other research data. The thermophiles isolated and screened for lipases are unique and novel.

Fermentation media containing different oils were used for batch fermentation for producing lipase using the four isolated bacteria culture from oil spilled soil. The bacterial strain was grown in the production media and amount of lipase produced was calculated using titration. Optimization of $\mathrm{pH}$, temperature, substrate, and incubation, etc., was performed for increasing production of lipase by the isolated bacterial culture. Different oils like mustard oil, soyabean oil and sunflower oil were mostly used as an alternative substrate for enzyme production. The maximum lipase enzyme activity obtained was $7 \mathrm{U}$ by P. mirabilis on $6^{\text {th }}$ day when sunflower oil was used as a carbon source and $6.5 \mathrm{U}$ was produced by $B$. coagulans on $6^{\text {th }}$ day. Soyabean oil gave the next highest amount of lipase enzyme activity.

In another study by Kumar et al., a thermophilic isolate B. coagulans BTS-3 produced an extracellular alkaline lipase, the production of which was substantially enhanced when the type of carbon 


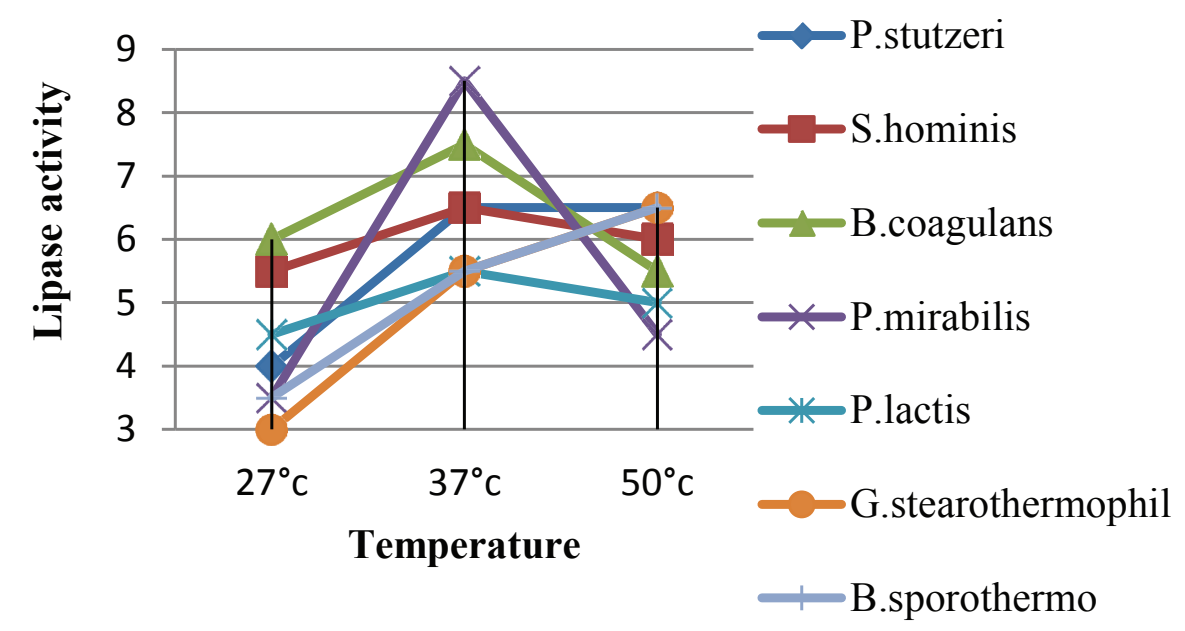

Figure 5: Lipase activity with change in temperature for incubation.
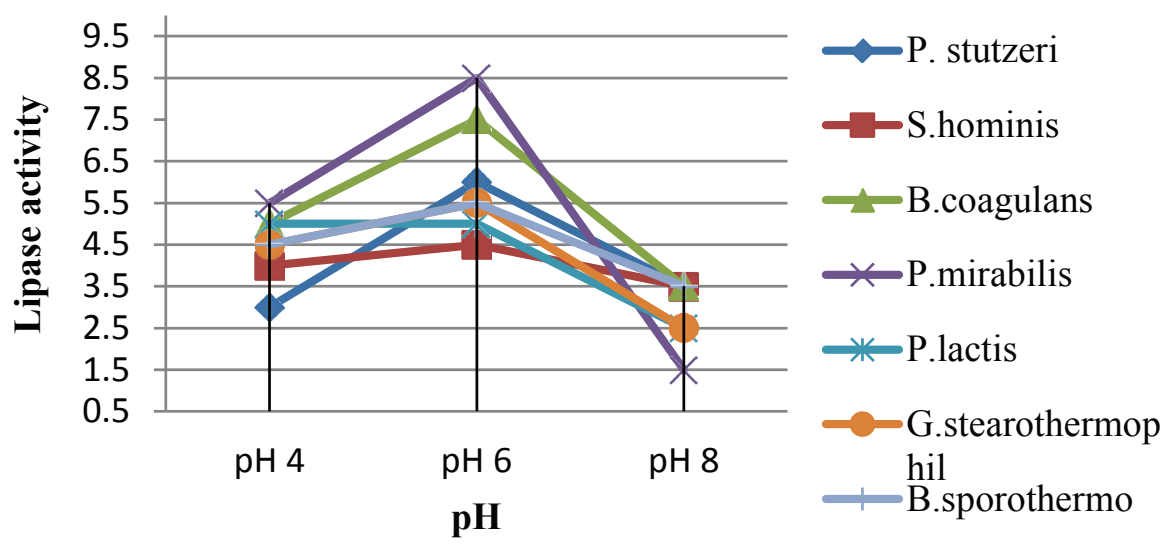

Figure 6: Effect of pH on lipase activity.

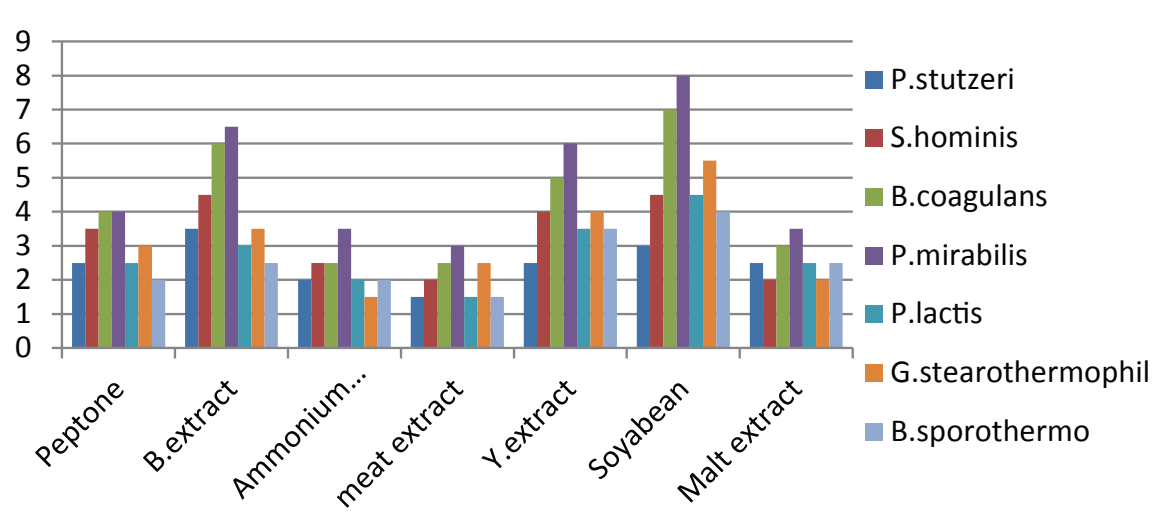

Figure 7: Effect of nitrogen sources on lipase activity.

source, nitrogen source, and the initial $\mathrm{pH}$ of culture medium were consecutively optimized [14]. Lipase activity $1.16 \mathrm{U}$ of culture medium was obtained in $48 \mathrm{~h}$ at $55^{\circ} \mathrm{C}$ and $\mathrm{pH} 8.5$ with refined mustard oil as carbon source and a combination of peptone and yeast extract (1:1) as nitrogen sources. Thus, in the present study a production of $7.5 \mathrm{U}$ of lipase enzyme activity gives a very high level of production.
In the present study, different temperature such as $25^{\circ} \mathrm{C}, 37^{\circ} \mathrm{C}$ and $50^{\circ} \mathrm{C}$ were used to check the optimum temperature for the lipase production by isolated bacteria culture. The maximum lipase enzyme activity obtained was $6.5-8.5 \mathrm{U}$ in all fermentation broth culture on $37^{\circ} \mathrm{C}$ and $50^{\circ} \mathrm{C}$.The fermentation media having different $\mathrm{pH}$ such as 4,6 , and 8 were used for isolated bacteria culture. The maximum lipase enzyme 
activity obtained was at $\mathrm{pH}$ 6. The lipase enzyme activity was 7.5-8.5U on $4^{\text {th }}-6^{\text {th }}$ day at $\mathrm{pH} 6$ media. Nitrogen source variation was also used for optimization of Lipase activity. Soyabean extract was found to lead to highest lipase activity by $P$. mirabilis.

Another related study by Larbi Daouadji et al. provided an overview about the effect of incubation time, medium $\mathrm{pH}$, temperature, carbon source and nitrogen source for the lipase production was studied [17]. The lipase production they showed were maximum at $\mathrm{pH} 8$, temperature $40^{\circ} \mathrm{C}$ and incubation time $48 \mathrm{~h}$ by the lipase producing bacteria $B$. licheniformis. With a selected carbon source, olive oil and glucose were suitable substrates to maximize lipase production (1.5 $\mathrm{U})$. The optimized concentration of olive oil and glucose was $1 \%$ and $1 \%$, respectively. The effect of nitrogen source on lipase production indicated that the yeast extract was suitable substrates for accelerating lipase production $(1.47 \mathrm{U})$.

Another important aspect in the present study was isolation of three thermophiles namely: G. stearothermophilus, B. sporothermodurans and $P$. stutzeri which produced around $4 \mathrm{U}$ of lipase enzyme activity at $37^{\circ} \mathrm{C}$ while producing $6.5 \mathrm{U}$ at $50^{\circ} \mathrm{C}$. These results show that these three bacterial cultures were indeed thermophiles as their optimum temperature for maximum lipase production is $50^{\circ} \mathrm{C}$.The amount of lipase activity produce in the present study is comparable and more than all earlier literature and studies.

\section{Conclusion}

Our present study provides useful information for the optimization of culture conditions such as $\mathrm{pH}$, temperature, fermentation time, and carbon sources to provide the best lipase production. These results show that lipase producing bacteria are widespread in oil contaminated soil. The sunflower oil is good substrate for lipase production and better than soyabean oil and mustard oil. The optimized growth conditions developed in this study can be used for a large scale in industrial purposes.

\section{References}

1. Kim GJ, Choi GS, Kim JY, Lee JB, Jo DH, et al. (2002) Screening, production and properties of a stereo specific esterase from Pseudomonas sp. S34 with high selectivity to (S)-ketoprofen ethyl ester. J Mol Catal B-Enzym 17:19-38.
2. Ohnishi K, Yoshida Y, Sekiguchi J (1994) Lipase production of Aspergillus oryzae. J Ferment Bioeng 77: 490- 495.

3. Falch EA, Falch EA (1991) Industrial enzymes developments in production and application. Biotechnol Adv; 9:643-658.

4. Fuji T, Tatara T, Minagawa M (1986) Studies on application of lipolytic enzyme in detergent industries. J Am Oil Chem Soc 63:796-799.

5. Sharma R, Christi Y, Banerjee UC (2001) Production, purification, characterization and application of lipases. Biotech Adv 19:627-662.

6. Linko YY, Lamsa M, Wu X, Uosukainen E, Seppala JM, et al. (1998) Biodegradable products by lipase biocatalysis. J Biotechnol 66: 41-50.

7. Hasan F, Shah AA, Hameed A (2006) Industrial applications of microbial lipases. Enzyme Microbial Tech 39: 235-251.

8. Eugene WS (1974) Industrial application of microbial lipases: A review. J Am Oil Chem Soc 51: 12-16.

9. Bajpai $P$ (1999) Application of enzymes in the pulp and paper industry Biotechnol Progr 15:147-157.

10. Noureddini H, Gao X, Philkana RS (2005) Immobilized Pseudomonas cepacia lipase for biodiesel fuel production from soybean oil. Bioresour Technol 96: 769-777.

11. Nakamura K, Nasu T (1990) Enzyme containing bleaching composition. Japanese Patent 2: 208-400.

12. Higaki S, Morohashi M (2003) Propionibacterium acnes lipase in seborrheic dermatitis and other skin diseases and Unsei-in Drugs. Exp Clin Res 29:157159 .

13. Kamini NR, Mala JGS, Puvanakrishnan R (1998) Lipase production from Aspergillus niger by solid-state fermentation using gingelly oil cake. Process Biochem; 33: 505-511.

14. Kumar S, Kikon K, Upadhyay A, Kanwar SS, Gupta R (2005) Production, purification and characterization of lipase from thermophilic and alkaliphilic Bacillus coagulans BTS-3. Protein Expr Purif 41: 38-44.

15. Pualsa Jagdish, Verma Deepa, Gavankar Rohan, Bhagat RD (2013) Production of microbial lipases isolated from curd using waste oil as a substrate. Res J Pharma Biol Chem Sci 4: 831.

16. Zouaoui B, Bouziane A (2011) Isolation, optimisation and purification of lipase production by Pseudomonas aeruginosa. J Biotechnol Biomateria 1:7.

17. Larbi Daouadji K, Benattouche Z, Abbouni B (2014) Screening selection identification production and optimization of bacterial lipase isolated from industrial rejection of gas station. J Chem Pharm Res 6: 455-459. 